\title{
Non-linguist future teachers' translation skills of structurally different clauses
}

\author{
Linda Chmelařová
}

\begin{abstract}
The paper deals with future teachers' (non-linguists') translation skills of chosen sentences from English to the Czech language. The chosen structures are complex sentences with a subordinate clause containing an ing-participle and these sentences are structurally different from their Czech equivalents. The theoretical part analyses Czech verbal tendencies and English nominal tendencies which result in the structural differences of both languages. The practical part describes the research and offers evaluation of the translation of particular sentences with regards to their structural character.
\end{abstract}

Key words: non-linguists, translation skills, subordinate non-finite clause, ing-participle, verbal and nominal tendencies. 


\title{
Dovednost budoucích učitelů nefilologických předmětů překládat strukturálně odlišné věty
}

\begin{abstract}
Abstrakt
Př́spěvek se zabývá dovednostmi budoucích učitelů nefilologického zaměření v oblasti překladu vybraných větných celků z angličtiny do češtiny. Vybrané větné struktury jsou souvětí s vedlejší větou, která obsahuje ing příčestí a je strukturálně odlišná od svého českého ekvivalentu. Teoretická část také analyzuje verbální tendence češtiny a nominální tendence angličtiny, které mají za následek strukturální odlišnosti obou jazyků. Praktická část popisuje samotný výzkum a nabízí vyhodnocení překladu jednotlivých vět s ohledem na jejich strukturální charakter.
\end{abstract}

Klíčová slova: nefilologové, překladové dovednosti, vedlejší nefinitní věta, ing příčestí, verbální a nominální tendence.

\section{Introduction}

This article is an attempt to consider the translation skills of future teachers with respect to those teachers who do not major in a foreign language but are trained for teaching other subjects at the lower secondary school level. At the beginning of their studies students choose English or alternatively German and Russian. In this article we will deal with English language development as this is by far the most common language chosen by students. The content of the English course may differ depending on the preference either to improve students' general English or develop their English for specific purposes in particular education.

To narrow the topic and have a deeper insight into the issue, we have decided to focus on their translation skills; since the translation in ELT has been disputed for the last couple of decades and it is finding its place in teaching, supporting successful acquisition of the English language. The theoretical section will present a language item which is structurally different in English and Czech.

\section{Structural differences between English and Czech}

English and Czech are typologically different languages with differences evident in, beside others - phonological, morphological and syntactical levels. This article will focus on an example of syntactical difference, specifically "condensed clauses". To explain this diversity, firstly it is necessary to point to the nominal tendencies in English and verbal 
tendencies in Czech which influence many structural aspects of both languages. The Oxford Concise dictionary (OCDL 2007) explains "nominalization" as a process in which a noun or a syntactic unit with the function of noun phrase is derived from any other kind of unit. Thus, nominal structures are either nouns, noun phrases or other language structures with the function of nouns. For instance:

I was smoking. -) I had a smoke.

They solved the problem -) their solution of the problem

Vachek (1990) paid attention to this issue having stated that English tends to use nominal structures to express the circumstances which are expressed by finite verbs in Czech. Semantically important information is expressed in the nominal part of the sentence which also has an impact on the structure. For instance:

I do the shopping every week. -) Nakupuji každý týden.

Let's have a rest. - Odpočiňme si.

Nominalization is also evident in more complex structures. Vachek says that "the information which is expressed by a subordinate clause or another main clause in Czech is embodied in English sentence by the nominal element" (Vachek 1990, s. 24). As a result of this, complex structures in English are more "condensed" and shorter in a written text. Hornová (1983) points out that many linguists dealt with the sentence condensation by defining the sentence elements which cause this condensation, namely infinitive, participle and gerund. All of these forms are non-finite structures, thus they cannot serve as the root of an independent clause and are signs of nominal tendencies in English.

\section{Participle clauses in English and Czech}

This article will primarily focus on the ing-participle, its function in the sentence and its structural manifestation in Czech equivalent sentences. When the ing-participle follows an element of substantive character, i.e. subject, object and complement, it develops this element. Frequently used sentences containing the ing-participle include subordinate clauses of circumstance, relative clauses and various types of adverbial clauses often derived from the conjunction used within the sentence. For instance:

1. I sat on the sofa talking to my friend. - Subordinate clause of circumstance.

2. I visited my father living in my home town. - Relative subordinate clause.

3. I found the key when going home. - Subordinate adverb time clause.

The specific feature of these sentences is that their Czech equivalents often differ structurally as the Czech language prefers finite verbs to non-finite ones. In the first case, the structurally identical Czech form is the adverbial participle (prechodník) which is an ob- 
solete structure which even most Czechs cannot correctly use. For this reason it is more convenient to use the finite verb form in the subordinate clause or other main clause.

Structurally identical form: Sedèl jsem na pohovce povídaje si se svým prítelem.

Structurally unidentical forms: Seděl jsem na pohovce a povídal si se svým prítelem. or Seděl jsem na pohovce, když jsem si povídal se svým přítelem.

In the second case it is also possible to use either identical (non-finite verbs) or nonidentical (finite verbs) structures in the Czech translation. Compared to the previous example, the identical form does not sound so obsolete, but it is still more preferable to choose the latter in the Czech language.

Structurally identical form: Navštívil jsem svého otce, žijicího $v$ mém rodném městě.

Structurally nonidentical form: Navštívil jsem svého otce, kterýžije v mém rodném městě.

In the last case the choice of finite verb form in the Czech equivalent is enhanced by the existence of the conjunction which does not allow many other possibilities.

Structurally nonidentical form: Našel jsem ten klič, kdyžjsem šel domů.

This structural disproportion was proved in the contrastive analysis which was carried out by Chmelařová (2010). The given structures were selected from fiction for adults, fiction for children and technical texts, and compared to their Czech equivalents in their published translations. This analysis confirmed that verbal tendencies represented by finite verbs in Czech are evident in comparison with nominal tendencies represented by non-finite verbs in English.

\section{Translation skills of future teachers}

English for non-linguists which is taught in the Faculty of Education at Palacký University is primarily focused on general English using a course book common for teaching various age groups from the lower-secondary schools to adult courses. As with most of the other English course books, it is used internationally, thus the use of the mother tongue is minimalized as well as using translation as one of the methods for improving language competence. Similarly at the lower educational levels it is up to the teacher whether they include translation in their teaching plan.

The practical goal of this article is to find out students' (future teachers) skills in translating structures analyzed in the previous paragraphs from English to their mother tongue. The translation from English to Czech has been chosen deliberately as minimum attention is paid to this particular skill. It demands not only knowledge of the 
target language but it also demonstrates whether students are aware of specifics of their mother tongue and are able to use it naturally. At the same time this way of developing students' language skills supports cross-curricular links between English and Czech language which is emphasized in the Framework Educational Programme.

\section{Specification of the test used in the research}

The types of sentences to be translated were chosen on the basis of the contrastive analysis (specifically fiction for adults) mentioned before, i.e. their constant ratio was maintained in this analysis. The overall number of sentences was 15; namely 7 clauses of circumstance, 5 relative clauses and 3 other adverbial clauses with a variety of conjunctions. The vocabulary selected for the test was adjusted to the level of students so as not to influence general translation skills as the focus in this test was on structural skills. Potentially difficult vocabulary was translated for the students. For the purpose of this research the same test as the one in the author's dissertation thesis was used (Chmelařová, 2010) since it fulfils all demanded requirements. The sample of the students involved is comparable and the language skills of University students in their first year are similar to those of students at grammar schools. The sentences given to the students are the following:

1. I left the school feeling a bit sick.

2. She put the silver plates on the table standing in the corner.

3. You are not allowed to enter the room if smoking.

4. John nodded, thinking about his new plan.

5. He looked through the window, sitting in his favourite sofa.

6. Staring at his new car, we walked out of the garage.

7. She couldn't find her mobile phone ringing somewhere in the room.

8. ... Peter asked, smoking his cigarette.

9. Steve didn't repeat it with the teacher standing behind him.

10. Smiling at his new colleague, he signed the paper.

11. She always sits in the garden, observing her small cats.

12. I sat there while trying to answer the questions.

13. All the boys playing in the street are my cousins.

14. Suddenly I met my friend talking to my new neighbour.

15. When leaving the church, he noticed that broken window.

When evaluating the students' translations, the focus was on the choice of the Czech structure of particular sentences, i.e., whether it structurally suits the English non-finite form and whether it is or is not used correctly; or if it contains the finite verb form in the subordinate or other main clause which sounds more natural in the Czech language. 
Another option was to omit a verb completely and use a kind of prepositional phrase which in some cases is grammatically and semantically acceptable. Any structure which contradicted grammatical rules of the Czech language was considered as incorrect.

\section{Specification of the students tested in the research}

The research sample consisted of 21 students (non-linguists) who study in the Faculty of Education, Palacky University and are not majoring in any foreign language but are future teachers being prepared for the profession in which they will specialize in other school subjects. The students were given the presented structures with a task of translating them into their mother tongue.

\section{Results of the research}

The following chart presents all Czech structural forms chosen by the students when translating the particular English sentences. The horizontal scale shows English sentences in the order as they were written in the test and the vertical scale show the students numbered from 1 to 21 . The abbreviations were used to condense the results into a clear survey presenting all translations given by the students.

\begin{tabular}{|c|c|c|c|c|c|c|c|c|c|c|c|c|c|c|c|}
\hline & 1 & 2 & 3 & 4 & 5 & 6 & 7 & 8 & 9 & 10 & 11 & 12 & 13 & 14 & 15 \\
\hline 1 & SC & SC & SC & SC & SC & $x$ & SC & $x$ & SC & SC & $x$ & SC & SC & SC & SC \\
\hline 2 & SC & NSC & SC & $X$ & MC & $x$ & NSC & $x$ & NSC & $x$ & $M C$ & SC & SC & SC & SC \\
\hline 3 & $X$ & NSC & SC & $x$ & $M C$ & $x$ & $x$ & $M C$ & NSC & $x$ & $M C$ & $x$ & $x$ & $x$ & SC \\
\hline 4 & $M C$ & NSC & SC & $X$ & SC & $X$ & SC & $x$ & SC & $X$ & $x$ & SC & NSC & NSC & $S C$ \\
\hline 5 & MC & SC & SC & MC & $M C$ & $M C$ & SC & MC & SC & MC & MC & SC & SC & NSC & SC \\
\hline 6 & NV & NSC & SC & $x$ & $x$ & $X$ & NSC & $x$ & SC & MC & MC & SC & SC & SC & SC \\
\hline 7 & NV & NSC & SC & $x$ & $x$ & $x$ & NSC & $x$ & NSC & $x$ & NSC & SC & NSC & NSC & SC \\
\hline 8 & $M C$ & NSC & SC & $x$ & $M C$ & $x$ & NSC & $x$ & NSC & $x$ & $x$ & SC & SC & NSC & SC \\
\hline 9 & SC & $x$ & SC & SC & SC & $x$ & SC & $x$ & NSC & SC & MC & SC & NSC & SC & SC \\
\hline 10 & SC & SC & SC & SC & MC & SC & SC & SC & SC & SC & $M C$ & MC & SC & SC & SC \\
\hline 11 & NV & NSC & SC & $x$ & $x$ & $X$ & SC & SC & SC & $x$ & NSC & SC & SC & SC & SC \\
\hline 12 & NV & NSC & SC & $x$ & $x$ & $x$ & NSC & SC & $x$ & $x$ & NSC & SC & NSC & SC & SC \\
\hline 13 & NV & $x$ & $x$ & $x$ & SC & $x$ & SC & $x$ & $x$ & $x$ & $x$ & SC & SC & $x$ & SC \\
\hline 14 & $x$ & NV & SC & NV & $x$ & $x$ & NSC & SC & NSC & $x$ & $x$ & SC & SC & NSC & SC \\
\hline 15 & $x$ & SC & SC & $x$ & $M C$ & SC & SC & $x$ & SC & $x$ & NV & SC & SC & SC & SC \\
\hline
\end{tabular}




\begin{tabular}{|c|c|c|c|c|c|c|c|c|c|c|c|c|c|c|c|}
\hline & 1 & 2 & 3 & 4 & 5 & 6 & 7 & 8 & 9 & 10 & 11 & 12 & 13 & 14 & 15 \\
\hline 16 & MC & NSC & SC & X & X & X & NSC & SC & X & NSC & X & X & NSC & NSC & SC \\
\hline 17 & SC & X & SC & SC & SC & X & SC & SC & NSC & SC & SC & SC & SC & SC & SC \\
\hline 18 & SC & SC & X & X & X & X & SC & SC & MC & X & MC & X & SC & SC & SC \\
\hline 19 & SC & SC & SC & X & NV & X & SC & X & SC & X & X & MC & SC & SC & SC \\
\hline 20 & SC & NV & SC & SC & MC & MC & SC & SC & NV & MC & MC & MC & SC & SC & SC \\
\hline 21 & NV & SC & $X$ & X & SC & MC & NSC & SC & SC & SC & MC & X & SC & SC & SC \\
\hline
\end{tabular}

Legend: SC - Finite subordinate clause, NSC - Non-finite subordinate clause, MC - Main clause, NV - Non-verbal form, X - Incorrect translation

To get the partial results, it is necessary to assess the translation of English structures separately, i.e. adverbial clauses of circumstances $(1,4,5,6,8,10,11)$, relative clauses $(2,7,9,13,14)$ and other adverbial clauses $(3,12,15)$.

As mentioned above, the first type of adverbial clause contains the participle which develops the subject of the main clause and its Czech equivalent form (přechodník) is considered obsolete. Out of all Czech structures used by the students ( 21 students $\times 7$ sentences $=147$ translations) only 4 of them were used correctly while keeping its direct equivalent. On the other hand, a large number of incorrect translations appeared (69), which is almost $47 \%$ and this result was probably caused by the fact that the students do not know how to use these Czech identical forms correctly and often use structures which do not exist or do not follow Czech grammatical rules. The insignificant number is represented by non-verbal forms (10) which shows the students' attempt to avoid using the Czech equivalent completely. The results, including use of finite subordinate clauses and main clauses are also relatively high; there are 28 main clauses and 36 finite subordinate clauses, in which the students added a conjunction of their choice to keep the semantic content of the sentence. Nevertheless, when analysing the translation of adverbial clauses of circumstance there are evident tendencies to choose identical non-finite forms which in the overwhelming majority are incorrect, meaning there is a lack of attention paid to English nominal and Czech verbal tendencies in the students' translations.

The second type of analysed sentence is relative subordinate clauses containing non-finite forms of the ing-participle; in the test 5 sentences of this type were included (in total 105). To summarise the results, the majority of the Czech structures chosen by the students for subordinate clauses in these sentences were finite subordinate clauses represented by finite verb forms (56). It is evident that translating relative clauses and respecting English and Czech structural differences is much easier for students than in the previous adverbial clauses of circumstance. A small number of incorrect translations (10) is proof of this. A tendency to keep the same structure is still quite strong as 35 translations contained Czech non-finite verb forms. Nevertheless, unlike in the 
first type of sentences, Czech non-finite verb forms used for relative clauses are much more common, thus, students are used to using them correctly despite Czech verbal tendencies. Only in minimum of the translations non-verbal (3) or other main clauses (1) were used.

The last sentence type was represented by other adverbial clauses whose relation to the main clause was characterised by conjunctions (in total 63). As assumed in the theoretical part, existence of conjunctions can positively influence students' choice of appropriate finite sub-ordinate clause in their translations. A vast majority of the translations (53) were such Czech clauses. There appeared only 7 incorrect translations and 3 other main clauses.

For better illustration a chart with all results and their rounded proportions is included:

\begin{tabular}{|l|c|c|c|c|c|}
\hline & X & SC & MC & NSC & NV \\
\hline Adverbial cl. of circumstances (147) & $69(47 \%)$ & $36(24,5 \%)$ & $28(19 \%)$ & $4(2,7 \%)$ & $10(6,8 \%)$ \\
\hline Relative clauses (105) & $10(9,5 \%)$ & $56(53,3 \%)$ & $1(1 \%)$ & $35(34,3 \%)$ & $3(2,9 \%)$ \\
\hline Other adverbial clauses (63) & $7(11,1 \%)$ & $53(84,1 \%)$ & $3(4,8 \%)$ & $0(0 \%)$ & $0(0 \%)$ \\
\hline
\end{tabular}

\section{Conclusion}

As the research has shown, students' ability to translate non-finite clauses containing the ing-participle from English into Czech with regards respecting different structural tendencies in both languages, is partly influenced by the type of clause. The most difficult for students to translate are adverbial clauses of circumstance which commonly appear in English. First, students do not respect the verbal character of the Czech language as they choose structurally identical forms but due to their lack of knowledge of these forms their translation is grammatically incorrect in most cases. Relative clauses are less difficult for students, even though they do not always respect verbal tendencies of the Czech language, their choice of form is mostly correct even though these include nominal structure which is more typical for English. The easiest clauses to translate for students are other adverbial clauses in which the conjunctions lead students to correct translations.

To sum, the results of the research given have proved students' lack of ability in translating structurally different forms from English into Czech. One of the reasons may be the fact that practising this specific translation skill is often neglected in all levels of education, as much more emphasis is placed on improving all basic skills (speaking, listening, writing, reading) and language aspects (grammar, vocabulary) with minimum attention paid to English language and mother tongue. If teachers use translation as one of the tools for achieving the expected students'language acquisition, they mostly 
focus on translating from their mother tongue into English which is very useful but it does not emphasize Czech structural characteristics. Translating into the mother tongue supports cross-curricular links and prepares students for correct interpretation of the information from English into Czech whilst respecting not only grammatical accuracy but also typology of both languages.

\section{References}

Agnew, D. (1994). Kondenzovanost anglických vět a jejich překlad do češtiny (Diplomová práce). Dostupné na filozofické fakultě Univerzity Palackého v Olomouci na katedře anglistiky a amerikanistiky.

Baranová, E. (1995-1996). Používanie materinského jazyka na hodinách cudzieho jazyka. Cizí Jazyky, 39 (7-8), 115-116.

Duff, A. (1996). Translation. Oxford, England: Oxford University Press.

Dušková, L. (1994). Mluvnice současné angličtiny na pozadí češtiny. Praha: Academia.

Fenclová, M. (1998-1999). Úloha mateřštiny v didaktice cizích jazyků. Cizí jazyky, 42 (1-2), 3-4.

Hornová, L. (1987). České ekvivalenty některých anglických větných kondenzorů po předložkách a spojkách. Philologica, 57, 17-32.

Hornová, L. (1983). Poznámka k funkci a překladu -ing tvarů jako větných kondenzorů. Philologica, 49, 21-32.

Chmelařová, L. Didaktická funkce překladu ve výuce AJ (Dizertační práce). Dostupné z https://theses. cz/id/ueibns/DIZERTACNI_PRACE.pdf

Knittlová, D. (1990). Funkční styly v angličtině a češtině. Olomouc: Univerzita Palackého v Olomouci. Levý, J. (1983). Umění překladu. Praha: Panorama.

Vachek, J. (1990). A linguistic characterology of modern English. Praha: Státní pedagogické nakladatelství.

\section{Contact:}

Institute of Foreign Languages

Faculty of Education, Palacký University in Olomouc

Žižkovo nám. 5, 77140 Olomouc, Czech Republic

E-mail: linda.chmelarova@upol.cz

Linda Chmelařová, Ph.D. primarily deals with organizing English language courses for nonlinguists in the Faculty of Education, i.e. students not majoring in Teaching English as a foreign language. Her research focuses on improving future lower secondary teachers'language competencies and their language needs analysis. In the research area she is also focused on the role of translation in English language teaching (especially in the context of Czech-English structural differences) and students' translation skills. In her profession she contributes to development of the international cooperation of the Institute of foreign languages with the Universities mostly from the Western Europe. She also teaches Language practice for primary students and participates in their evaluation. 